\title{
POTENSI BAKTERI ASAM LAKTAT SEBAGAI KANDIDAT PROBIOTIK ANTIMIKROBA PATOGEN ASAL FERMENTASI KAKAO VARIETAS CRIOLLO
}

\section{THE POTENTIAL OF LACTIC ACID BACTERIA AS PROBIOTIC CANDIDATE ANTIMICROBIAL PATHOGEN FROM COCOA FERMENTATION CRIOLLO VARIETY}

\author{
Urnemi $^{1}$, Sumaryati Syukur ${ }^{2}$, Endang Purwati ${ }^{3}$, Sanusi Ibrahim ${ }^{4}$, Jamsari ${ }^{5}$, \\ ${ }^{1}$ Laboratorium Bioteknologi Fakultas Pertanian, Jurusan Agroteknologi, Universitas \\ Mulawarman Samarinda Kalimantan Timur \\ Email : urnemisyuib@ymail.com \\ ${ }^{2}$ Laboratorium Bioteknologi Fakultas Matematika Ilmu Pengetahuan Alam, Jurusan \\ Kimia, Universitas Andalas Padang Sumatera Barat \\ ${ }^{3}$ Laboratorium Bioteknologi Fakultas Peternakan, Jurusan Mikrobiologi, Universitas \\ Andalas Padang Sumatera Barat \\ ${ }^{4}$ Laboratorium Kimia Organik Fakultas Matematika Ilmu Pengetahuan Alam, Jurusan \\ Kimia, Universitas Andalas Padang Sumatera Barat \\ ${ }^{5}$ Laboratorium Bioteknologi Fakultas Pertanian, Jurusan Agroteknologi, Universitas \\ Andalas Padang Sumatera Barat
}

Naskah diterima 19 Maret 2012, disetujui 8 Oktober 2012

\begin{abstract}
ABSTRAK
Bakteri Asam Laktat (BAL) diisolasi dari fermentasi buah kakao pada hari ke-3 fermentasi yaitu pada varietas Criollo, semua terdapat 11 isolat. Isolat-isolat tersebut diberi nama $\mathrm{Gr}$. yaitu $\mathrm{Gr} 3(1,2,3, \ldots .11)$. Semua isolat diuji terhadap aktivitas antimikrobial pada lima bakteri patogen indikator (Escherichia coli 14237, Staphylococcus aureus NBRC 13276, Bacillus subtilis BTCCB 612, Listeria monocytogenesis dan Salmonella typhii). Dipilih satu isolat yang potensial (memilki diameter zona hambat tertinggi terhadap lima bakteri patogen). Isolat potensial tersebut kemudian dilakukan uji dengan menggunakan Sodium Dodecyl Sulfate Polyacrylamide Gel Electrophoresis (SDS-PAGE), yaitu untuk melihat bobot molekul bakteriosinnya. Hasil uji aktivitas antimikrobial menunjukan bahwa, 11 isolat BAL asal fermentasi kakao tersebut memiliki zona hambat berkisar antara $7 \mathrm{~mm}-11 \mathrm{~mm}$ sampai pengamatan 48 jam. Ditemukan satu isolat potensial yaitu isolat Gr3.7 yang memiliki daya hambat yang tertinggi terhadap 5 bakteri uji, diameter zona hambatnya berkisar $11 \mathrm{~mm}$ terhadap Salmonella typhii dan Listeria monocytogenesis sampai 48 jam pengamatan. Hasil uji bobot molekul protein bakteriosin (bakteriosin belum dimurnikan) diperkirakan bakteriosin dari isolat Gr2.7 adalah $24 \mathrm{kDa}$. Kandidat probiotik Gr3.7 dapat digunakan sebagai anbiotik alami, karena memiliki respon positif terhadap Salmonella typhii, Salmonella typhii terkenal dengan bakteri patogen pada saluran pencernaan, juga digunakan sebagai bahan pengawet alami (food preservative), Karena
\end{abstract}


sangat respon terhadap patogen Listeria monocytogenesis, yang dikenal sebagai patogen pada pencemaran pangan.

Kata Kunci : Bakteri asam laktat (BAL), probiotik, kktivitas antimikroba, SDS

\section{ABSTRACT}

Lactic Acid Bacteria (LAB) were isolated from cocoa beans three days fermentation Criollo variety. That were eleven isolates, all of isolates were named Gr3 (1, 2, 3, 4,..,11). All of isolates were tested to antimicrobial activity against indicator pathogenic bacteria (Escherichia coli 14237, Staphylococcus aureus NBRC 13276, Bacillus subtilis BTCCB 612, Listeria monocytogenesis dan Salmonella typhii), than that was chosen potential one isolate had highest inhibition zones to pathogens. One potential isolate was done determination weigh protein bacteriocin by Sodium Dodecyl Sulfate Polyacrylamide Gel Electrophoresis (SDS-PAGE). Result of antimicrobial activity test showed that, 11 isolates had inhibition zone to pathogenic bacteria, that were $7 \mathrm{~mm}$ till $11 \mathrm{~mm}$ at 48 hours observation. That was found one isolate potential, it was Gr3.7. Gr3.7 isolate had high inhibition zones to against growth pathogenic bacteria, that was $11 \mathrm{~mm}$ to Salmonella typhii and Listeria monocytogenesis at 48 hours observation. Determination crude weight protein test was estimated $24 \mathrm{kDa}$ protein by using SDS-PAGE. To Found purifying weight protein bacteriocin must be done purification processing. Probiotic candidate (Gr3.7) can be used as natural antibiotics, because it had positive responce to against Salmonella typhii. Salmonella typhii was known pathogen in intestine, beside that it was used as food preservative, because it had positive response to against Listeria monocytogenesis.

Keywords : Lactic acid bacteria (LAB), antimicrobial activity, SDS-PAGE

\section{PENDAHULUAN}

B akteri Asam Laktat merupakan organisme berse tunggal, termasuk bakteri Gram positif dan anaerob fakultatif, tidak membentuk spora, berbentuk batang dan kokus, mampu memproduksi asam laktat sebagai hasil metabolisme selnya. Pada mulanya BAL terdiri dari 4 genus yaitu Lactobacillus, Leuconostoc, Pediococcus dan Sterptococcus. Seiring berkembangnya kemajuan molekular, tahun 1980-an genus BAL berkembang menjadi 20 genus. Secara generatif BAL tidak bersifat patogen atau berbahaya. BAL merupakan jenis mikroorganisme yang aman (food grade microorganism), dalam kategori Generally Recognized As Safe (GRAS) (Marteau, 2002).

Saarela et al. (2000) menyatakan, secara umum BAL dapat menhasilkan senyawa metabolit, yaitu 1) Asam Organik. Jenis asam organik yang dihasilkan tergantung pada spesies BAL, komposisi kultur dan kondisis pertumbuhan BAL. Asam organik yang banyak dihasilkannya adalah asam laktat. Manfaat asam laktat antara lain menurunkan $\mathrm{pH}$ saluran pencernaan, memperbaiki pemanfaatan mineral $\mathrm{Ca}$, $\mathrm{P}$ dan $\mathrm{Fe}$, menstimulir sekresi asam lambung, meningkatkan pristaltik lambung, berfungsi sebagai energi pada proses respirasi. 2) Hidrogen Peroksida 
dan $\mathrm{CO}_{2}$, Enzim piruvat oksidase merubah piruvat menjadi $\mathrm{CO}_{2}$ dan Hidrogen peroksida $\left(\mathrm{H}_{2} \mathrm{O}_{2}\right)$. Efek bakterisidal dari $\mathrm{H} 2 \mathrm{O} 2$ adalah terjadinya oksidasi sel bakteri sehingga mendenaturasi sejumlah enzim. 3). Komponen Aroma. Semua BAL melakukan fermentasi asam sitrat menghasilkan senyawa diasetil menghasilkan aroma. Senyawa asetil ini juga bersifat antimikroba dengan menghambat pertumbuhan bakteri gram negatif. 4). Bakteriosin, BAL menghasilkan baketriosin yaitu peptida yang bersifat sebagai bakteriosidal, maka demikian BAL dinamakan juga dengan probiotik.

BAL sebagai probiotik merupakan bagian dari flora normal pada saluran pencernaan (Sujaya et al. 2008). Probiotik dari BAL dapat memberikan efek yang menguntungkan bagi kesehatan seperti menurunkan kadar kolesterol (Pereira et al., 2003; Yulinery et al., 2006; Purwati, 2006; Belviso et al., 2009; Lee et al., 2010), pencegahan kanker kolon dan usus (Brady et al., 2000; Pato, 2003; Liong, 2008), dan penanggulangan dermatitis atopik pada anak-anak (Betsi et al., 2008; Torii et al., 2010), membantu untuk absorpsi nutrisi, mengurangi tekanan darah tinggi, membantu pencernaan laktosa bagi penderita lactose intolerance (Salminen, Wright dan Ouwehand, 2006). penanggulangan diare (Salazar et al., 2007; Pant et al., 2007; Tabbers dan Benninga, 2007; Collado et al., 2009), menstimulasi sistem kekebalan (immune) tubuh (Isolauri et al., 2008; Isolauri dan Salminen, 2008).

BAL dapat diisolasi dari produk fermentasi hewan dan tanaman, seperti pada produk hewani yaitu pada susu dan olahannya, dan pada saluran pencernaan. Pada buah-buahan dan sayuran, BAL dapat diisolasi dari buah sirsak, nenas, acar, kopi dan kakao fermentasi. Pada biji kopi dan biji kakao, BAL berguna untuk meningkatkan kualitas baik segi rasa, warna dan aroma, selain itu Efek bakterisidal dari asam laktat berkaitan dengan penurunan $\mathrm{pH}$ lingkungan menjadi 3 sampai 4,5 sehingga pertumbuhan bakteri pembusuk akan terhambat, mengakibatkan biji kopi dan biji kakao akan memiliki daya simpan yang lebih lama. Pada umumnya mikroorganisme dapat tumbuh pada kisaran pH 6-8 (Taylor, 2004). Prinsip kerja BAL yaitu dengan memanfaatka kemampuan mikroorganisme tersebut dalam menguraikan rantai panjang karbohidrat, protein dan lemak. Kemampuan ini diperoleh karena adanya enzim-enzim khusus yang dimiliki oleh mikroorganisme untuk memecah ikatan. Pemecahan molekul kompleks menjadi molekul sederhana mempermudah penyerapan oleh saluran pencernaan. Di sisi lain, mikroorganisme pemecah ini mendapat keuntungan berupa energi yang diperoleh dari hasil perombakan molekul kompleks (Stanton et al., 2001). Penggunaan probiotik merupakan solusi dari upaya pengurangan penggunaan antibiotik yang telah menimbulkan kekhawatiran masyarakat karena munculnya resistensi antibiotik baik pada manusia maupun hewan dan efek residu yang tertinggal dalam produk seperti unggas (Patterson dan Bulkholder, 2003).

(2003)

karakteristik BAL yang berasal dari tanaman berbeda dengan BAL yang berasal dari susu. Kemampuan dari masing-masing BAL dalam memfermentasi berbagai jenis karbohidrat juga berbeda, meskipun memiliki strain yang sama. Contoh Lactobacillus delburuckii ssp. bulgaris asal susu tidak bias tumbuh pada tanaman karena tidak dapat memanfaatkan maltose, sedangkan Lactobacillus delburuckii ssp. bulgaris yang berasal dari sari buah tidak bisa ditumbuhkan pada susu karena tidak bisa memfermentasi laktosa. 
Untuk mendapatkan BAL yang potensial perlu dilakukan skrining BAL terhadap aktivitas antimikroba, yang nantinya akan digunakan sebagai kandidat probiotik. BAL potensial, akan memiliki nilai yang tinggi untuk diaplikasikan yaitu di bidang kesehatan (obat-obatan), keamanan pangan (food safety), di bidang peternakan sebagai probiotik/supplement. (Purwati, et al., 2005).

Menurut Okade (2003), BAL dapat diisolasi dari tanaman dan saluran pencernaan hewan atau produk yang berasal dari hewan, seperti susu fermentasi, akan tetapi karakteristik BAL yang berasal dari tanaman berbeda dengan BAL yang berasal dari susu, hal ini disebabkan pada tanaman banyak terdapat senyawa metabolit sekunder bioflavonoid yang dapat bersifat antioksidan.

Telah banyak dilakukan penelitian uji aktivitas antimikroba BAL pada produk fermentasi susu (yogurt, dadih, keju,) (Syukur dan Purwati, 2006). Namun pada kakao varietas Criollo, fermentasi 3 hari dan uji berat molekul krud bakteriosin dengan menggunakan SDS-PAGE belum pernah dilaporkan.

Dari penelitian ini diharapkan bakteriosin yang dihasilkan dari BAL tersebut dapat digunakan sebagai bahan antibiotik alami di bidang kesehatan, pengawet alami untuk bahan makanan seperti perikanan (susu, daging, telur, ikan dan udang) maupun produk olahan lainnya seperti keju, sosis dan baso.

\section{METODE PENELITIAN}

\section{Bahan yang digunakan.}

Buah kakao varietas Criollo, media de Mann Ragosa Sharpe Agar (MRS Agar) (Oxoid), de Mann Ragosa Sharpe Broth (MRS Broth) (Oxoid), Nutrien agar (NA), Nutrient broth (NB), $\mathrm{NaOH}, \mathrm{HCl}$, $\mathrm{MgCl}$, Bakteri patogen uji (Escherchia coli NBRC 14237, Staphylococcus aureus NBRC 13276, Bacillus subtilis BTCCB 612, Listeria monocytogenesis, Salmonella typhii, antibiotik Penicillin, 11 isolat BAL Gr3. (1, 2, 3, ... 11), glyserol $15 \%$, gel SDS poliakrilamid, Comassie Brilliant Blue R-250.

\section{Alat yang digunakan}

Paper test steril, cawan petri, tabung reaksi, sentrifugasi, mikro pipet, inkubator BAL, inkubator bakteri patogen, lemari pendingin $-20^{\circ} \mathrm{C}$, $4^{\circ} \mathrm{C}$, Laminar Air Flow Cabinet (LAFC), autoklaf, pinset.

\section{Isolasi Bakteri Asam Laktat}

Bakteri asam laktat diisolasi dari fermentasi biji kakao varietas Criollo pada hari ke-tiga fermentasi. Ditimbang $10 \mathrm{~g}$ sampel, kemudian ditambahkan dengan $90 \mathrm{ml}$ MRS Broth, divortek dan dihomogenkan selama 2 menit, setelah itu dilakukan pengenceran sampai $10^{-7}$, kemudian diisolasi pada 2 cawan petri yang berisi media MRS agar, diinkubasi pada temperatur $37^{\circ} \mathrm{C}$ selama 24 jam di dalam inkubator. Setelah tumbuh 11 singel koloni dimurnikan sebanyak 3 kali pemurnian, disubkultur dalam MRS broth (Leisner et al., 1997).

\section{Uji Aktivitas Antimikroba}

Uji aktivitas antimikroba dilakukan terhadap lima bakteri uji yaitu (Escherichia coli 14237, Staphylococcus aureus NBRC 13276, Bacillus subtilis BTCCB 612, Listeria monocytogenesis dan Salmonella typhii) (Koleksi Laboratorium Bioteknologi Virologi LIPI. Cibinong Bogor). Metoda yang digunakan adalah metoda difusi paper test steril assay (Mustopa, 2007). Kultur BAL $1 \mathrm{ml}$ disentrifugasi dengan kecepatan $6000 \mathrm{rpm}$ selama 5 menit pada suhu $4^{\circ} \mathrm{C}$, kemudian supernatannya digunakan untuk uji aktivitas antimikroba. Bakteri patogen yang akan diuji dimasukkan sebanyak $200 \mu \mathrm{l}$ ke dalam $20 \mathrm{ml}$ media nutrien 
agar (NA) yang masih cair, suhu berkisar antara $40^{\circ} \mathrm{C}$. Hasil campuran dihomogenkan, kemudian dituang ke dalam cawan petri steril. Dibiarkan selama 30 menit agar mengeras. Setelah media mebeku diteteskan $20 \mu \mathrm{l}$ supernatant BAL dengan mikropipet ke atas paper test steril tersebut, sebagai kontrol positif diberi Antibiotik testing paper yang telah steril dengan diameter $6 \mathrm{~mm}$, setelah itu diinkubasi pada suhu $37^{\circ} \mathrm{C}$ secara anaerob. Kemudian dilakukan pengamatan selama 48 jam terhadap zona hambat/zona bening, yang memperlihatkan zona bening disekitar paper test tersebut, setiap pengamatan dilakukan pengukuran diameter zona hambat tersebut (Hollo et al., 1991).

\section{Karakterisasi Berat Molekul Bakteriosin dengan menggunakan Sodium Dodecyl Sulfate Polyacrylamide Gel Electrophoresis (SDS-PAGE)}

Tahapan

karakterisasi

Bakteriosin bakteri asam laktat $\mathrm{Gr} 3.7$ menggunakan metoda (Laemmli, 1970). Diawali dengan analisis bobot molekul peptida menggunakan elektroforesis $15 \%$ gel SDS PAGE. Supernatan dimasukkan sebanyak $20 \mu \mathrm{L}$ ke sumur/lobang agar elektroforesis.
Marker pembanding yang digunakan memiliki 9 polypeptida yaitu 200, 150, $100,75,50,37,25,20$, dan $10 \mathrm{kDa}$, digunakan sebagai marker. Setelah selesai elektroforesis SDS poliakrilamid, gel diwarnai dengan pewarnaan perak (silver stainning) Comassie Brilliant Blue R-250 hingga muncul pita-pita, lalu dioptimasi dengan menggunakan Marker pembanding.

\section{HASIL DAN PEMBAHASAN}

\section{Isolasi Bakteri Asam Laktat (BAL)}

Setelah dilakukan isolasi BAL pada pengenceran $10^{-7}$ didapatkan koloni BAL sepertipada Gambar 1a, selanjutnya dikoleksi 11 koloni, kemudian dilakukan pemurnian sebanyak tiga kali (Gambar 1b.), kultur hasil pemurnian disimpan pada MRS broth dengan penambahan $15 \%$ glyserol pada $-70^{\circ}$ C. Kultur yang akan digunakan untuk uji selanjutnya disimpan dalam MRS broth pada suhu $-4^{0} \mathrm{C}$ dan disubkultur setiap interfal waktu 4 minggu. 11 isolat BAL tersebut akan diuji terhadap aktifitas antimikroba.

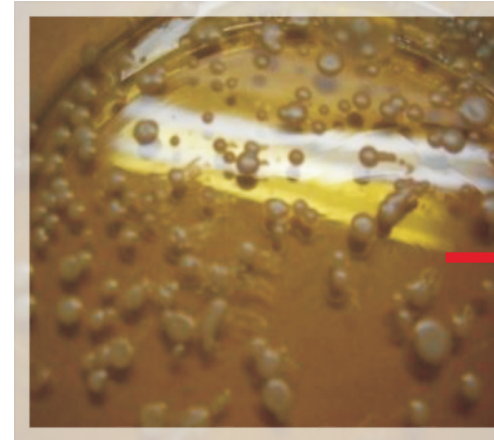

(a)

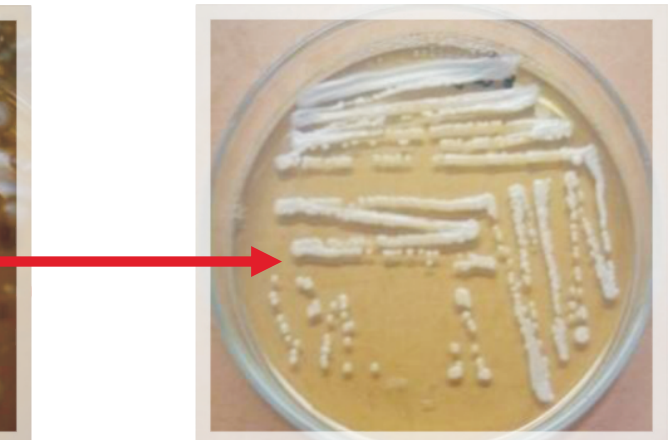

(b)

Gambar 1. Bakteri asam laktat pada MRS agar (Oxoid)

Ket. : a dan $b=B A L$ pada MRS agar (Oxoid), Koleksi 11 isolat BAL, $b=$ pemurnian tiga kali 


\section{Uji Aktifitas Antimikroba}

Hasil penelitian aktifitas antimikroba 11 isolat bakteri asam laktat yang diisolasi dari fermentasi 3 hari kakao varietas Criollo dapat dilihat pada Tabel 1 berikut :

Table 1. Aktifitas antimikroba 11 isolat bakteri asam laktat asal 3 hari fermentasi kakao varietas Criollo pada media MRS agar dengan menggunakan uji paper diffusion assay 48 jam.

\begin{tabular}{lccccccc}
\hline Isolat & $\begin{array}{l}\text { Penicillin } \\
\text { (+kontrol) }\end{array}$ & $\begin{array}{l}\text { Bacillus } \\
\text { subtilis } \\
\text { BTCCB }\end{array}$ & $\begin{array}{l}\text { E.coli } \\
\text { NBRC } \\
\text { 14237 }\end{array}$ & $\begin{array}{l}\text { Listeria } \\
\text { monocytoge } \\
\text { nesis }\end{array}$ & $\begin{array}{l}\text { Staphylococcus } \\
\text { aureus } \\
13276\end{array}$ & $\begin{array}{c}\text { Salmonella } \\
\text { NBRC }\end{array}$ & thypii \\
\hline Gr3.1 & 9 & 9 & 7 & 9 & 8 & 8 \\
Gr3.2 & 9 & 9 & 9 & 8.5 & 8 & 9.2 \\
Gr3.3 & 9 & 9.5 & 9.5 & 9 & 9.5 & 9 \\
Gr3.4 & 9 & 9.6 & 9 & 9 & 9 & 9.5 \\
Gr3.5 & 9 & 9 & 9.7 & 9 & 9 & 9 \\
Gr3.6 & 9 & 9.5 & 9 & 9 & 10 & 9 \\
Gr3.7 & 9 & 10 & 10 & 10 & 10 & 11 \\
Gr3.8 & 9 & 9 & 9 & 9.6 & 9 & 9 \\
Gr3.9 & 9 & 9 & 8.9 & 9 & 9.5 & 9.7 \\
Gr3.10 & 8 & 9.7 & 9 & 9 & 9 & 9 \\
Gr3.11 & 8 & 9 & 9 & 9.5 & 9 & 9.5 \\
\hline
\end{tabular}

Pada Tabel 1 menunjukan bahwa, diameter zona hambat terhadap pertumbuhan bakteri patogen dari 11 isolat BAL bervariasi antara $7 \mathrm{~mm}$ sampai $11 \mathrm{~mm}$. Isolat Gr3.7 memiliki zona hambat terhadap pertumbuhan 5 bakteri patogen yang paling tinggi, yaitu $10 \mathrm{~mm}$ sampai $11 \mathrm{~mm}$. Isolat Gr3.7 ini paling potensial menghambat Salmonella thypii dengan diameter zona hambat $11 \mathrm{~mm}$ (Gambar 2.), dan juga potensial terhadap Listeria monocytogenesis, Escherichia coli 14237, Bacillus subtilis dan Stapilococcus aureus. Menurut Purwati (2003), Listeria monocytogenesis. adalah bakteri patogen dominan pada pangan. Sebelumnya Leisner et al. (1997) menyatakan bahwa BAL sebagai probiotik dapat melindungi makanan atau dapat membunuh bakteri patogen sebagai bahan pengawet pangan yang disebut (food preserfatif).

Hasil uji aktivitas antimikroba tersebut, isolat $\mathrm{Gr} 3.7$ sangat potensial menghambat pertumbuhan Listeria monocytogenesis, Stapilococcus aureus NBRC 13276 dan Salmonella thypii, oleh karena itu isolat Gr3.7 dapat dijadikan sebagai kandidat probiotik pada manusia, hewan dan pangan.

Salmonella thypii adalah penyebab utama dari penyakit tifus yang disebarkan melalui makanan (foodborne diseases). Pada umumnya Salmonella menyebabkan penyakit pada organ pencernaan yang disebut salmonellosis. Ciri-ciri orang yang mengalami salmonellosis yaitu mengalami diare, keram perut, dan demam dalam waktu 8 - 72 jam setelah memakan makanan yang terkontaminasi oleh Salmonella. Bakteri 
ini masuk ke dalam pembuluh darah dan gastroenteritis, yang disebabkan oleh keracunan makanan/intoksikasi. Salmonella typhii memiliki keunikan hanya menyerang manusia, dan tidak ada inang lain (Maloy, 1999).

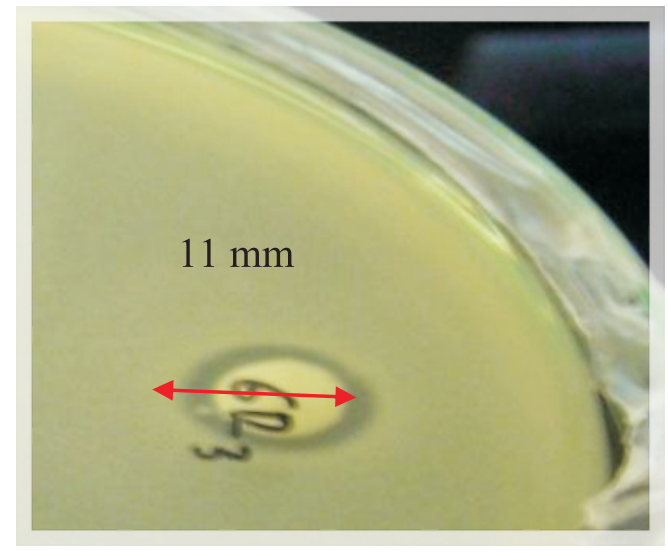

Gambar 2. Uji Aktifitas isolat Gr3.7 terhadap bakteri patogen

\section{Karakterisasi Berat Molekul Protein isolat Gr3.7 dengan SDS-PAGE}

Berat molekul protein isolat
Gr3.7 dideterminasi dengan
menggunakan Sodium Dodecyl Sulfate
Polyacrylamide Gel Electrophoresis
(SDS-PAGE) (Gambar 3), Pita yang
ditunjukan setelah diberi pewarnaan
Stain Comassie Blue diperkirakan
berkisar pada posisi $24 \mathrm{kDa}$. Jika
dibandingkan dengan hasil penelitian
dari Kiran-Kumar et al. (2009) hasil
pemurnian bakteriosin dari
Pediococcus acidilactici asal fermentasi sayuran, didapatkan hasil berat molekul protein klas Ila, anti-listerial berat molekol bacteriosin adalah $5 \mathrm{kDa}$, lebih kecil jika dibandingkan dengan berat molekul protein bakteriosin Gr3.7. Hal ini disebabkan karena bakteriosin isolat Gr3.7 belum dilakukan pemurnian (krud bakteriosin). Untuk melakukan pemurnian bakteriosin melalui tahap pengendapan ammonium sulfat dan kolom kromatografi ion exchange. Berarti $24 \mathrm{kDa}$ adalah berat molekul protein dari $\mathrm{Gr} 3.7$ yang masih $\mathrm{krud} /$ kotor (belum dimurnikan).

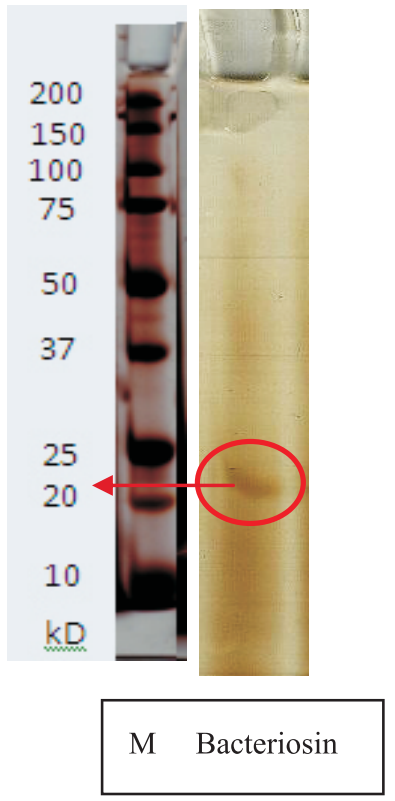

Gambar 3. SDS-PAGE dari Kultur krud isolat Gr3.7, Lane 1; molekular markers, lane 2; Berat molekul krud Gr3.7

\section{KESIMPULAN}

Isolat Gr3.7 adalah isolat berasal dari kakao fermentasi 3 hari varietas Criollo. Isolat tersebut memiliki daya hambat yang tinggi terhadap bakteri patogen Escherichia coli 14237 NBRC 14237, Staphylococcus aureus NBRC 13276, Bacillus subtilis BTCCB 612, Listeria monocytogenesis dan Salmonella thypii dan dengan zona hambat $10 \mathrm{~mm}-11 \mathrm{~mm}$ sampai 48 jam pengamatan. Isolat Gr3.7 memiliki berat molekul protein krud adalah 24 $\mathrm{kDa}$. Melihat tingginya potensi daya hambat terhadap lima bakteri patogen uji, maka isolat ini bisa digunakan sebagai kandidat probiotik pada manusia seperti antidiare, anti penyakit tifus dan dapat digunakan sebagai bahan pengawet pangan alami/food preservative, karena sensitif terhadap Listeria. 


\section{UCAPAN TERIMA KASIH}

\begin{abstract}
Penulis mengucapkan terima kasih kepada Laboratorium Bioteknologi Virologi LIPI Bakosurtanal Cibinong Bogor, Indonesia. Laboratorium Mikrobiologi Fakultas Peternakan, Laboratorium Bioteknologi Fakultas Pertanian Universitas Andalas Padang. Penelitian ini didanai oleh Hibah Disertasi Doktor , Kerja sama DIKTI dengan LEMBAGA PENELITIAN UNIVERSITAS ANDALAS Padang, NOMOR: $\quad$ 006/UN.16/PL/DD/V/2011 dan Beasiswa Pemprov KALTIM. Sebagian data ini telah diseminarkan di "The $2^{\text {nd }}$ International Seminar on Chemistry 24-25 Nov. 2011 Univ. Padjadjaran" sebagai presenter.
\end{abstract}

\section{DAFTAR PUSTAKA}

Belviso, S., M. Giordano, P. Dolci and G. Zeppa. 2009. "In vitro cholesterol-lowering activity of Lactobacillus plantarum and Lactobacillus paracasei strains isolated from the Italian Castelmagno PDO cheese". Dairy Sci. Technol. 89 : 169-176.

Betsi G. I., E. Papadavid and M.E. Falagas. 2008. "Probiotics for the Treatment or Prevention of Atopic Dermatitis: A Review of the Evidence from Randomized Controlled Trials". Am. J. Clin. Dermatol. 9(2) : 93 - 103.

Brady, L.J., D.D. Gallaher and F.F. Busta. 2000. "The Role of Probiotic Cultures in the Prevention of Colon Cancer". J. Nutr. $130:$ 410-414.

De Man., J. C. Rogosa, and M. E. Sharpe, 1960. "A medium for the cultivation of lacto-bacilli: $J$. Appl.Bacteriol., vol. 23, hal. 130135.

Holo H, Nilssen and Nes IF. 1991. "Lactococcin A, a new bacteriocin from Lactococcus lactis Subsp. cremoris: isolation and characterization of the protein and its gene". Journal of Bacteriology; (38): 79-87.

Isolauri, E. and S. Salminen. 2008. "Probiotics: Use in Allergic Disorders: a Nutrition, Allergy, Mucosal Immunology, and Intestinal Microbiota (NAMI) Research Group Report". J. Clin. Gastroenterol. 42 (2) : 91 - 96.

Kiran-Kumar, P.V. Badarinath, and P.M. Halami. 2009. "Isolation of anti-listerial bacteriocin producing Lactococcus lactis CFR-B3 from Beans (Phaseolus vulgaris)". The Internet Journal of Microbiology. Volume 6 Number 1. hal 431-435

Laemmli, U.K., 1970. "Cleavage of structural proteins during the assembly of the head of bacteriophage T4". Nature, vol. 277: hal. 680- 685.

Lee, J., Y. Kim, H. S. Yun, J. G. Kim, S. Oh, and S. H. Kim. 2010. "Genetic and Proteomic Analysis of Factors Affecting Serum Cholesterol Reduction by Lactobacillus acidophilus A4". Appl. Environ. Microbiol. 76(14): 4829-4835.

Leisner, J. J., G. Rusul, B. W. Wee, H. C. Boo and K. Mohammad. 1997. "Microbiology of Chili Bo. A popular Malaysian food ingredient". Journal of Food Protection. 60:1 hal..235-1240.

Maloy, S. 1999. Salmonella Information. [terhubung berkala]. http://www. Salmonella.org/info.ht $\underline{m l}$. (Diakses tanggal11 Apr 2008].

Marteau, P. 2002. "Safety aspects of probiotic products". Scand J Nutr, (In Press).

Mustopa, A. 2007. Colection Protocol Laboratorium Biotechnology and Virology Moleculer. Biotechnology Research Center. LIPI. Bogor. 
Okade, S.,2003. "Lactic Acid Bacteria of plant origin: Characteristics and applications. Proceedings, The 2nd Asia Conference of Lactic Acid Bacteria", Taipei.1415.

Pant. N., H. Marcotte, H. Brüssow, L. Svensson and L. Hammarström. 2007. "Effective Prophylaxis Against Rotavirus Diarrhea Using a Combination of Lactobacillus rhamnosus GG and Antibodies". BMC Microbiol. 7 (86): 2180 2187.

Pato, U. 2003. "Potensi bakteri asam laktat yang diisolasi dari dadih untuk menurunkan resiko penyakit kanker". Jurnal Natural Indonesia. Vol. 5(2): 162-166.

Patterson, J.A. and K.M. Burkholder. 2003 "Application of prebiotics and probiotics in poultry production". Poultry Science (82) 627-631.

Pereira, D.I.A., A.L. McCartney and G.R. Gibson. 2003. "An In Vitro Study of the probiotic Potential of a Bile-Salt-Hydrolyzing Lactobacillus fermentum Strain, and Determination of Its Cholesterol-Lowering Properties". Appl. Environ. Microbiol. 69 (8):4743-4752.

Purwati, E. 2003. Molecular chacarcterization of Listeria spp. isolated from beef, chicken and fermented fish. Universitas Putra Malaysia. Disertation.

Purwati, E., S. Syukur, dan Z. Hidayat. 2005. Lactobacillus sp. Isolasi dari Biovicophitomega sebagai Probiotik. Di dalam Proceeding Lembaga IImu Pengetahuan Indonesia, Jakarta.

Purwati, E., dan S. Syukur. 2006. Peranan pangan probiotik untuk mikroba patogen dan kesehatan. Universitas Andalas Padang.
Saarela, M., R. Monogensen, J. Fonden, J. Matto and T. MattilaSandholm. 2000. "Probiotikbacteria safety, functional and technological properties". J. Biotechnol. 84: 197-215.

Salminen, S., A. V., Wright, and A. Ouwehand. 2006. "Lactic Acid Bacteria: Microbiological and Functional Aspects", Fourth Edition. CRC Press. ISBN 978-08247-5332-0.Page.1

Sujaya, I N., Y. Ramona, N.P. Widarini, N.P. Suariani, N.M.U. Dwipayanti, K.A. Nocianitri dan N.W. Nursini. 2008. "Isolasi dan karakteristik bakteri asam laktat dari susu kuda Sumbawa" . J. Vet. 9 (2) : 52 $-59$.

Salazar-Lindo, E., D. FigueroaQuintanilla, M. I. Caciano, V. Reto-Valiente, G. Chauviere, and P. Colin. 2007. "Effectiveness and Safety of Lactobacillus LB in the Treatment of Mild Acute Diarrhea in Children". J. Ped. Gastroenterol. Nutr. 44:571-576.

Stanton, C., G. Gardiner, H. Meehan, K. Collins, G. Fitzgerald, P. B. Lynch, and R. P. Ross. 2001. "Market potential for probiotics". Am. J. Clin. Nutr. 73(Suppl.):476S-483S.

Tabbers, M.M. and M.A. Benninga. 2007. "Administration of probiotic lactobacilli to children with gastrointestinal problems" : There is Still Little Evidence. Ned. Tijdschr. Geneeskd. 151 (40) : 2198 - 2202.

Taylor, S. 2004. "Advances in Food and Nutrition Research", Vol. 50. Academic Press. ISBN 978-0-12016450-9.

Torii, S., A. Torii, K. Itoh, A. Urisu, A.Terada, T. Fujisawa, K. Yamada, H. Suzuki, Y. Ishida, F. Nakamura, H. Kanzato, D. Sawada, A. Nonaka, M. 
Hatanaka, and S. Fujiwara. 2010. "Effects of Oral Administration of Lactobacillus acidophilus L-92 on the Symptoms and Serum Markers of Atopic Dermatitis in Children". Int. Arch. Allergy Immunol. 154(3): 236-245.
Yulinery, T., E. Yulianto dan N. Nurhidayat. 2006. "Uji fisiologis probiotik lactobacillus sp mar 8 yang telah dienkapsulasi dengan menggunakan spray dryer untuk menurunkan kolesterol".

biodiversitas 7 (2) : 118 - 122. 